\title{
THE VALUE AND CHARACTER BUILDING EDUCATION IN FOLKLORE FROM BATAKNESE "SIGALE-GALE"
}

\author{
${ }^{1,2}$ Ria Anita Sipahutar, ${ }^{1}$ Remlinawati Siantury, \& ${ }^{1}$ Yenita Sembiring, \\ ${ }^{1}$ English Student, English Language Education, University of Prima Indonesia \\ ${ }^{2}$ Corresponding Author Email: sipahutarrya@gmail.com
}

\begin{tabular}{|c|c|}
\hline Article Info & Abstract \\
\hline $\begin{array}{l}\text { Article History } \\
\text { Received: November } 2020 \\
\text { Revised: January } 2020 \\
\text { Published: January } 2020\end{array}$ & $\begin{array}{l}\text { Education is the learning of knowledge, the skills of every person that are passed } \\
\text { down from generation to generation for one generation. But in education, it is } \\
\text { also essential to learn the formation of good character. In this relevant research, } \\
\text { especially those that raise Folklore as the object of study, only a few people know }\end{array}$ \\
\hline $\begin{array}{l}\text { Keywords } \\
\text { Moral values; } \\
\text { Character building; } \\
\text { Sigale-gale Folklore; }\end{array}$ & $\begin{array}{l}\text { about it. Folklore is a medium that can use as a means of forming positive } \\
\text { characters in children through moral values and character education contained } \\
\text { in the story. This type of research is qualitative descriptive obtained, analyzed, } \\
\text { and analyzed in writing to describe the moral values and character building } \\
\text { contained in the Toba Batak folklore "Sigale-gale." Data collection was carried } \\
\text { out by reading the Sigale-gale folklore text repeatedly and identifying the data in } \\
\text { the form of keywords related to the values forming the characters in the story. } \\
\text { Furthermore, the collected data were analyzed using content analysis techniques. } \\
\text { The results showed that there were four character-forming values in the Sigale- } \\
\text { gale Folklore; namely hard work, curious, friendly, and wise. }\end{array}$ \\
\hline
\end{tabular}

How to cite: Sipahutar, A. S., Siantury, R., \& Sembiring, Y. (2021) The Value and Character Building Education in Folklore from Bataknesse "Sigale-gale". .JOLLT Journal of Languages and Language Teaching, 9(1), 111-116. DOI: https://doi.org/10.33394/jollt.v\%vi\%i.3228

\section{INTRODUCTION}

Education is the learning of knowledge, skills of each person passed down from generation to generation. In shaping quality human resources, education must have good character and moral values. Education should be useful for the academic field and have good moral and character values. Muslich (2013) states that character education should take precedence because it is in a better park, elementary school, junior high school, middle school, and university. Therefore, internalization of the values of character education must begin at the necessary level of formal education and have to do to various environments such as at school, family, and community life. The purpose of the realization and implementation of character education is to make students have good skills, good knowledge, and morality.

Students must not only be useful in academics but also have to be right. That is because higher education must have good morals. Thus, education produces extraordinary output with great characters (Youpika, 2016). According to Aynur (2011), Character Education is a national movement creating a school that fosters ethical, responsible, and caring young people by modeling and teaching good character through an emphasis on universal values that all share. However, the phenomenon in our lives is not in line with expectations, for examples of many facts that show the use of electronic and social media deviations such as Facebook, Instagram, and games. The use of the internet is so out of control that children can access it freely.

Furthermore, based on several researchers' observations, there are still many students who need character education programs such as discipline, responsibility, doing homework on 
time, respecting friends and teachers, and being honest. It must be corrected by yourself. According to (Barone, 2011), Folklore is part of traditional literature.

The researchers take some previous study about the moral Value and character-building education in Folklore. The previous study's object is Moral Value Assessment and Character Education in Folklore in Karo District, The Value of Characteristic Education in Andai-Andai Folklore, the need for character education. Based on facts, Folklore has many benefits in the world of education, including cultivating moral values to build student character. one of the famous Folklore is the "Si Gale-Gale" folklore originating from Bataknesse, North Sumatra. This Folklore can be one of several alternative learning materials for students in junior high school. Awang (1985) states that Folklore has an entertaining function, teaching material, encouraging people to articulate polite words, and encouraging literature as the basis for doing literary works.

Based on the phenomenon, the researcher did this research to increase the knowledge taken by readers, and the research can be used as teaching material in junior high school because it contains moral Value and character building for children. Considering that Folklore has a pearl of local wisdom that contains educational values, it is necessary to develop and disseminate Folklore to future generations. In addition, many positive values can shape the character of children from an early age. This research hopes that inputs about life and Moral Value in Folklore can be obtained.

Researchers use descriptive qualitative, where researchers try to describe and interpret the elements in the story, situation and condition, symptoms, and development to see the contribution of the Value of the story on character education. In data collection, researchers conducted literature studies and observations.

\section{RESEARCH \\ Research Design}

This type of research is a Qualitative Descriptive Study. Meleong (In Hidayati, 2016: 38), Qualitative Descriptive means that the data generated and collected are in the form of words, pictures, through descriptions but not by numbers. Next, the data obtained will be processed and analyzed in written form. According to Moleong (in Hidayati,2016:38), Qualitative Research is an effort to present the social world, concepts, behaviours, perceptions, and human under study issues. This qualitative descriptive study is used to obtain an overview of displaying educational values in the "Sigale-gale" Batak folklore.

\section{Instruments}

As qualitative research should be, this research too a human instrument, to be precise, the researchers themselves. Humans are using it as a tool for collecting data based on criteria understood. The standard in question is knowledge of morals. The device in this research is a data card. They have used data cards to record and transcribe all data obtained.

\section{Data Analysis}

In KBBI (2001), analysis means an investigation of events (essays, deeds, and others.) to find out the situation the truth (causation, sit down the case, and so on). According to Sugiyono (2012), data analysis involves finding and compiling data obtained from interviews, notes fields, and documentation, with data organized into categories and break down into units. In addition, this study did synthesis, arrange in the pattern, choose what is essential and what will learn, and conclude it can quickly understand by oneself or others. This study used descriptive qualitative analysis techniques. Furthermore, the data obtained were processed and analyzed in written form. This descriptive analysis uses a pragmatic approach. According to Siswanto and Roekhan (in Siswanto, 2013), the pragmatic approach is a literary study approach that emphasizes his study of the reader's role in accepting, understanding, and living 
literary works. This pragmatic approach uses to analyze the educational values inSigale-gale Folklore, including the Value of moral education and the Value of social education.

The steps of data analysis performed are 1) classifying data, data obtained from the analysis of educational values contained in the Sigale-gale Folklore, namely in the form of Educational ValuesMoral and Value of Social Education; 2) data in the form of educational values such as; the Value of moral education and the Value of social education also are analyzed in terms of what behaviors or patterns. Those are containing in it. 3) Linking the educational values contained in folklore Sigale-gale with its application in learning moral values for the formation of character in students. 4) Summing up the results of the overall data analysis. Meanwhile, in a qualitative study, the author(s) should mention the model to analyze the data. This brief explanation is further followed by the application of each stage within the selected model.

\section{RESEARCH FINDINGS AND DISCUSSION Research Findings}

Research finding the data will be analyzed and interpreted based on the theory and research interpretation. The research finding in this research can be presented as follows.

\begin{tabular}{cc}
\hline & Moral Value in Sigale-gale Folklore \\
\hline Datu Panggana & Hard word and Curiosity \\
\hline Bao Partigatiga & Friendly \\
\hline Aji Bahirbahir & Wise \\
\hline
\end{tabular}

\section{Discussion}

This study was designed to analyze moral values and character formation in the Toba Batak folklore entitled Sigale-gale as learning for children in the formation of good moral values and character. The main focus of this research is to analyze the character of each character in the Folklore. From our findings, there are four moral values in character building, namely hard work, Curiosity, friendship, and wise, with the four characters in the Folklore as learning for students so that it is carried out in real life. The following is an explanation of the moral Value in the Sigale-gale Folklore.

\section{Hard work}

Hard work is a behavior that shows a genuine effort being to make to overcome various and learning and assignment obstacles. The Value of hard work can see in the narrative and quote below.

"There was a man. His name was Datu Panggana. He's an expert statue. He always sought materials for the statue himself. If a king wants to make a tomb, and for that, a stone statue is needed, so he went up and downhills. And valleys to find a suitable stone for that purpose. When a wooden statue is ordered, he goes out into the forest looking for suitable wood. That is how good he is with his job so that he is well known in his Huta (village). "(Sigale-gale, 1978: 5)

Based on the quotation above, Datu Panggana is a hard worker. He is willing to go up and down hills and go out into the forest to find the materials and needed for his work. According to Gunawan (2012) hard work is a behavior that shows serious effort to overcome various obstacles in order to complete tasks ( study work) as well as possible.

The hard work attitude shown in the character Datu Panggana is very important to be taught to students, so that students can instill hard work from an early age so that later they can become useful children. 


\section{Curiosity}

Curiosity is an attitude and action that always try to know more deeply and broadly something that is learning seen and heard. We can see the Value of Curiosity from the quote from the conversation between Datu Panggana and Bao Partigatiga below.

"What trade are you Par?" asked Datu Panggana, glancing at him serious obstacles hung on Bao Partigatga's shoulders." Trading pearls, gold jewelry, clothes. Uh, Datu, suddenly I got sense. This statue will be more beautiful if we give clothes and more jewelry. Can I try it Datu? "Suggested Bao Partigatiga suddenly. (Sigale-gale, 1978: 12)

In the quote above, it is clear to Datu Panggana's Curiosity, how the statue looks like when used for clothes and jewelry and because of that Datu Panggana asked Bao Partigatiga's permission to try it. According to Mustari (2011), curiosity is an attitude and action that always seeks to know more deeply and broadly from what one has learned, seen and heard, this is to obligations towards oneself and the environment.

Thanks to the curiosity of Datu Panggana, who always tries to decorate the statue, the statue is very beautiful and almost looks human. Datu Pangga's sense of curiosity attitude is an attitude that we need to teach children because curiosity can lead us to continue learning something.

\section{Friendly}

Friendships are actions that show a sense of pleasure in talking, socializing, and cooperating with others. We can see the Value of friendship from the following narrative quote.

"Because he wanted to find clothes that were equivalent to the image of a statue, Bao Partigatiga became so diligent that he tried all the clothes he was carrying, in turn, trying on the body of the statue. Finally, a pair of crimson clothes slung across the graceful girl's body, enhancing her dazzling face. As it is with clothes, so it is with jewelry. He tried all the jewelry on the body of the statue. Earring, necklaces, rings, various models, when he found the right jewelry, Bao Partigatiga jumped for joy like a child". (Sigale-gale, 1978: 14)

From the friendship shown by Bao Partigatiga, he is willing to help in choosing clothes and jewelry for the statue made by Datu Panggana, and it is also clear that Bao Partigatiga is happy to be able to choose clothes and jewelry for the statue. From the friendship attitude of the figure of Boa Partiga-Tiga who wants to help Datu Panggana to decorate the statue is an attitude that we must also teach to children. From a sense of friendship, we can get an attitude of tolerance and kinship between our neighbors to help each other in any situation.

Wise

Wise is an action or decision made by someone without burdening or causing loss to someone with another. Can see The Value of wisdom in the following narrative.

"Because Datu Partoar is the oldest among them, so like in front of the King, now he is the one who first spoke to Aji Bahirbahir. After hearing the description, the Aji Bahirbahir replied: "All problems will be solved if faced calmly. What is your real problem now? To the three of you, must consider all of you as having a family relationship with Nai Manggale. So the problem is, about family ties. So the only way is: you three, must consider all of you to have a family relationship with Nai Manggale. Judging by the services of each of you to Nai, I think it is best like this: Datu Partoar became his father, Bao Partigatiga became his brother, and Datu Panggana became his uncle. Hope you accept this decision because I am sure, Nai himself will surely feel sad 
if he finds out that he is the source of your constant bickering, "said the Aji Bahirbahir." (SGG, 1978: 42-43)

According to Kitchener \& Brenner (in Sternberg \& Jordan, 2005:17) argues wise as the intellect ability to realize limitation knowledge and how it impacts in solving problems that are not clear and make judgments. It is clear from the quote above with the wise of Aji Bahirbahir that $\mathrm{s}$ can resolve their problems. We have to instill this kind of attitude from an early age in children, so that later they can make it.

\section{CONCLUSION}

Based on the analysis of the character-forming values contained in the Sigale-gale Folklore, can conclude that in the Folklore, four character-forming values are founding, namely; hard-working, curious, friendly, thoughtful. One of the values that shapes character is the Folklore form. As a cultural heritage, Folklore needs to be preserved, processed and used as an essential medium in character education for the nation. The character-forming values contained in Folklore are not just to be understood but to be practised in everyday life. However, it is not only understanding that is important, but appreciation and practice in everyday life are equally important.

From the description of the character-forming ${ }^{7}$ values in Sigale-gale, it shows that the Folklore contains quite a lot of character-forming values that every human being especially needs to have in shaping students' character. By having these character-forming values, it will form better attitudes and morals. The character-forming values contained in the Sigale-gale are the message the author sends to the reader to imitate the good characters contained in the character of the story. Character-forming values must be instilled in students and implemented in real life to form positive attitudes and behaviors.

\section{ACKNOWLEDGEMENT}

Based on the results of the above research, the authors suggest that in this life it is appropriate to understand moral values and character building as a form of lessons that can learn so that life is living safer and more peacefully. For the next researcher, it is necessary to examine the contents in the Folklore of North Sumatra more deeply, especially the Batak Toba area with the title of the Sigale-gale story.

\section{REFERENCES}

Junaidi, F. (2017). The Value of character education in andai-andai Folklore and its use as learning material for elementary school literature. International E-Journal of Advances in Education, 3(9), 501-509. http://ijaedu.ocerintjournals.org/tr/issue/33256/370409

Pala, A. (2011). The Need for Character Education.International Journal of Social Sciences and Humanity Studies, 3(2), 23-32.

Wiryanota, S. (2016). Nilai-Nilai Pendidikan Dalam Cerita Rakyat Balang Kesimbar dan Hubungannya dengan Pembelajaran Sastra di SMP. Skripsi.Fkip Universitas Mataram.

Nurelide. (2007). Meretas Budaya Masyarakat Batak Toba dalam Cerita Sigalegale. Master.

Sayer, I. M., Kristiawan, M., \& Agustina, M. (2018). Fairy Tale as a Medium for Children's Character Cooperation Building.Al-Ta Lim Journal, 25(2), 108-116. https://doi.org/10.15548/jt.v25i2.458

Johardianto, Y. (2018). An Analysis of Moral Value in 47 Ronin Film. Jurnal Imiah Bahasa dan Sastra. 
Chowdhury, M. (2016). Emphasizing Morals, Values, Ethics, and Character Education in Science Education and Science Teaching. The Malaysian Online Journal of Educational Sciences (MOJES), 4(2), 1-16.

Moral Value Assessment And Character Education In Folklore In Karo District Karmila Br Karo Dosen PGSD Universitas Quality. (, 1973). 28-33.

Setyawati, E. (2013). AnalisisNilai Moral Dalam Novel Surat Kecil UntukTuhanKarya Agnes Davonar (PendekatanPragmatik). Journal of Chemical Information and Modeling, 53(9), 1689-1699.

Lubis, H. S., Nasution, I., \&Marsella, E. (2018).Karonese Perception on the "Si Beru Dayang "Folk Myth. 5(September), 201-204.

A. Kamaruddin, S. (2012). Character Education and Students Social Behavior. Journal of Education and Learning (EduLearn), 6(4), 223. https://doi.org/10.11591/edulearn.v6i4.166

Chowdhury, M. (2016). Emphasizing Morals, Values, Ethics, and Character Education in Science Education and Science Teaching. The Malaysian Online Journal of Educational Sciences (MOJES), 4(2), 1-16.

Nurmala, S. (2020). Nilai Moral Cerita Rakyat DalamBukuCerita Daerah Sulawesi Tenggara.Jurnal BASTRA (BahasadanSastra) 5(1), 45-56. http://ojs.uho.ac.id/index.php/BASTRA.

Warta, I. K. (2012). Developing Students' Moral Value Through Folklore in Multilingual Setting : a Case. 1-19.

RafyFitriani. (, 1965). An Analysis of Moral Values in Novel "Oliver Twist" By Charles Dickens Rafy Fitriani *), Rivi Antoni 1), Pipit Rahayu 2) 1\&2). https://docplayer.net/49792195-An-analysis-of-moral-values-in-novel-oliver-twist-bycharles-dickens-abstrak-abstract.html

Pusat Kurikulum dan Perbukuan, (2011). Panduan Pelaksanaan Pendidikan Karakter. Jakarta: BadanPenelitiandanPengembanganKemdiknas.

Koesoema, A. Doni. 2010. Pendidikan Karakter: Strategi Mendidik Anak di Zaman Global. Jakarta: PT Grasindo. 